\title{
The Using YouTube and Google Drive as Arabic Learning Media at Covid-19 Period
}

\author{
Mahyudin Ritonga ${ }^{1}$, Ahmad Lahmi $^{2}$, Fitria Sartika ${ }^{3}$, Zubaidah $^{4}$ and Fauzana Annova ${ }^{5}$ \\ \{mahyudinritonga@gmail.com\} \\ Muhammadiyah University of West Sumatera, Indonesia ${ }^{123}$, Institute Agama Islam Negeri \\ Bukittinggi, Indonesia ${ }^{4}$, Universitas Islam Negeri Imam Bonjol Padang, Indonesia ${ }^{5}$
}

\begin{abstract}
The current rapid development of technology becomes an alternative for learning continuity, especially in the Covid-19 conditions. However, many educators cannot apply the technology related to Arabic learning. This study described the Arabic learning model by utilizing YouTube and google drive. The findings of this study were that the learning materials arranged in accordance with the learning implementation plan, then entered into Google Drive. The videos related to the material were distributed to students to listen and recorded what they heard. The novelty of this research is that the YGD combination can be a solution for online language learning such as the Covid-19 condition. While the weaknesses of research are related to language learning material in the grammatical aspect where the model cannot be found, so it can be the work of future researchers.
\end{abstract}

Keywords: YouTube; Google Drive; Arabic Learning Media; Covid-19

\section{Introduction}

The Covid-19 condition requires every educator to be more creative and innovative in realizing interactive education. Various efforts are made by educators so that students can learning well and are able to achieve the learning objectives that have been set [1]. Even though some educators are still not able to fully utilize technology due to the limited infrastructure supporting [2]. There is also the unpreparedness of some educators or students to perform online learning through advanced technology, such as weak control of educators on IT and limited access to supervising students [3], so that students are less active in learning activities, or limited support facilities and internet network access.

However, based on research, the use of information technology is very helpful for the implementation of online learning during the Covid-19 pandemic [4], especially if connected to an internet network [5]. The use of technology in online language learning is required to make students active in learning and is necessary to consider its availability [6]. YouTube becomes the online learning media because it is accessible. Language development is also influenced by various social media used by the public. Currently, YouTube has been able to attract millions of human eyes to access it every day with various dishes contained in it.

According to Dwivedi et al YouTube becomes most popular video database in the internet world, contains many things, including learning materials, both for students and students and also for the general public [7]. The researchers are interested in conducting research on the use of YouTube and google drive as Arabic learning media. 
Previous researchers on online learning is about utilizing information and communication technology, such as Iqbal et al who conducted research on the use of google form media in online learning [8]. Iivari et al who discusses the transformation of learning media during the pandemic [9]. Fauzan and Arifin examined the use of google classroom media in online learning [10]. Nasution have also conducted research on the use of YouTube in Indonesian language learning [11], but research has not been found on learning Arabic using YouTube and google drive media. Therefore, it is important to conduct the research about YouTube and Google Drive as Arabic learning media.

\section{Method}

The approach used in this research was qualitative, this approach was chosen because it is related to the data to be found and analyzed in the form of informants' statements. Therefore, the data collection techniques used were observation, interviews and documentation. Observations were used to see firsthand how teachers and students use YouTube and Google Drive as a model for learning Arabic during the Covid-19 period. The interviews were used to obtain information related to teacher and student responses to Arabic learning using YouTube and Google Drive. The documentation is intended to obtain data about the results of learning Arabic using YouTube and Google Drive during the Covid-19 period as stated in the report on student learning outcomes.

The research data were analyzed qualitatively, starting from data collection, data classification, data reduction to conclusion. To examine the validity of the research data, the researcher used triangulation, both in the form of source triangulation, time triangulation, and technical triangulation.

\section{Result and Discussion}

Arabic learning is certainly different from other language learning. In Arabic learning the material presented must be able to improve four language competencies, namely listening, speaking, reading, and writing [12]-[13]. Integration of multimedia with all the sophisticated features in information technology allows educators to make the most in teaching Arabic to non-Arabic students. So that learning Arabic using YouTube and Google Drive is one of the solutions for Arabic educators in carrying out online learning during the Covid-19 outbreak in Indonesia.

According to Pratiwi and Hapsari the use of YouTube in learning is able to convey messages from educators to students [14]. In learning by using YouTube, educators can be as creative as possible to create interactive learning for students. Even though educators do not deal directly with students, the presentation of material on YouTube is able to suggest students to remain active during learning until they finish doing tasks or exercises like Arabic learning generally in face-to-face classes.

The first part of the material provided through YouTube is in the form of muhadatsah or a conversation between two characters that is packaged into an animated video and displayed very interestingly to be seen, listened to, and followed by students. At the beginning of the presentation of the material, the dialogue is full in Arabic without the help of text or translation, it is to see the extent to which learners are able to listen to Arabic dialogue and 
understand the contents of the dialogue before being given a translation. This opening material also makes students more focused and interested in paying attention from the start, because interest is the important factor in learning Arabic [15].

It needs to be serious in listening the Arabic dialogue, both the pronunciation, the expressions of the characters, and the purpose of the dialogue as a whole. Without full concentration, students will be difficult to respond and conclude the purpose of the dialogue, so that this opening material has succeeded in hypnotizing students to survive listening until the dialogue is complete.

After listening skills, the dialogue is repeated by including the dialogue text and the translated text, it is to practice pronunciation or speaking skills for students. By repeating what has been listened to at the beginning, students can pronounce the conversation according to the intonation and the text also helps students pronounce while memorizing the dialogue text. Translation also increasingly helps students in understanding the meaning of dialogue in each word and sentence. It really helps students in improving the ability to listen as well as pronounce and understand Arabic material. The two forms of presenting the material that have been able to make students feel comfortable and feel homey attending learning through the YouTube channel, and make the high curiosity for students with the continuation of the material through the video on YouTube.

After listening and dialogue skills, the video has not stopped, there is still a continuation in the form of mufradat material or Arabic vocabulary and the translation that can be written for students to memorize. Several mufradat related to material are included in the video along with the translation accompanied by a visual image, so that a mufradat is easy for students to remember. Colored script, pictorial, sound, and presented in YouTube videos is certainly very interesting for students and easy to memorize. The material through the YouTube channel ends with practice in writing and understanding the material from the start. There are some simple questions or exercises that must be done by students, so that without being ordered by the educator, students will understand for themselves that at the end of the material is an exercise that must be done.

The presentation of material through the YouTube channel can be repeated by students according to their needs, it can be played repeatedly without bothering the educator if someone forgets or falls behind in writing it down. Students can learn on their own and arrange the course of the video by themselves, whether to repeat a word, sentence, competency, or as a whole. It depends on the ability of students to understand this learning.

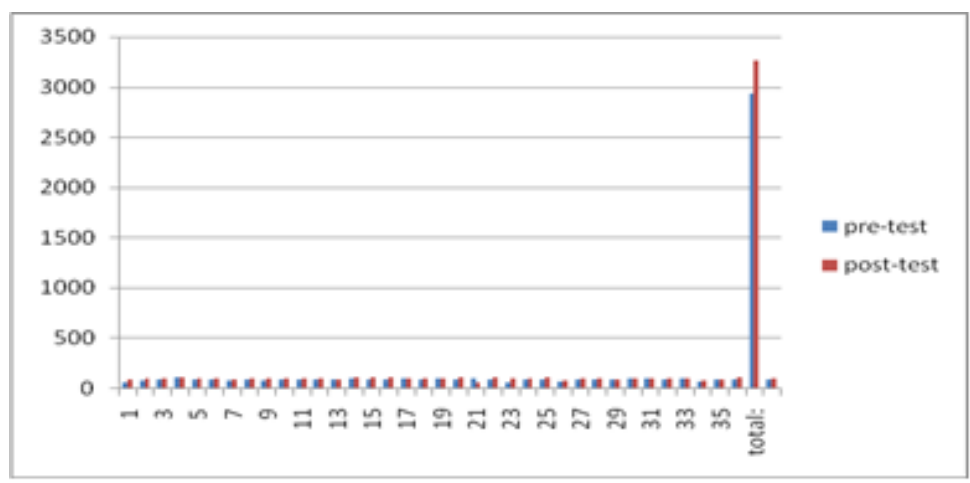

Fig 1. Learn Arabic Using YouTube and Google Drive 
Before the material is given to students, educators can save it on Google Drive, so that when the learning schedule students can receive the Google Drive link to access the learning material provided by the educator. Thus, online-based Arabic learning can still be carried out in a conducive and fun way without significant obstacles by both educators and students. This learning model is also able to overcome difficulties in online learning, especially in learning Arabic. It can also improve the quality of Arabic learning outcomes for students. As seen in the results of learning Arabic in class VII.3 MTsN 6 Solok Regency as figure 1.

The pre-test is the student daily Arabic test score before studying online using YouTube and Google Drive. Meanwhile, the post-test is the daily test score for Arabic students after learning to use YouTube and Google Drive. From the diagram, it can be seen that there is a significant increase in Arabic learning outcomes using YouTube and Google Drive. Of the 36 students, the total pre-test score was 2935, and the average was 81.5. Post-tests with a total number of 3260 and with mean of 90.6. From the results of the quiz, the percentage of improvement in learning outcomes can be measured as follows:

Percentage increase $(\%)=\underline{(\text { final }- \text { initial })} \times 100 \%$

Then, $\underline{3260-2935} \times 100 \%=11,07 \%$

2935

It means that there is an increase of Arabic learning outcomes by $11.07 \%$ by utilizing YouTube and Google Drive media. Generally, the learning media such as YouTube and google drive media also have strength and weakness among others, as in table 1 below:

Table 1. Strength and Weakness YouTube and Google Drive

\begin{tabular}{|c|c|}
\hline Strength & Weakness \\
\hline YouTube is easy to access & $\begin{array}{l}\text { Accessing and downloading videos on } \\
\text { YouTube requires a large quota }\end{array}$ \\
\hline $\begin{array}{l}\text { Simple editing available before } \\
\text { uploading of videos }\end{array}$ & $\begin{array}{l}\text { For elementary level students must be } \\
\text { accompanied by parents in accessing the } \\
\text { YouTube }\end{array}$ \\
\hline $\begin{array}{l}\text { Google drive can store a lot of } \\
\text { material to be taught }\end{array}$ & $\begin{array}{l}\text { Video that contains advertisements that } \\
\text { make the video cut off and not all } \\
\text { advertisements are worthy of being } \\
\text { watched by students }\end{array}$ \\
\hline $\begin{array}{l}\text { The access link can be arranged by } \\
\text { educators }\end{array}$ & $\begin{array}{l}\text { For students who live in low internet } \\
\text { areas, they cannot access it, because } \\
\text { accessing YouTube requires a good } \\
\text { internet network }\end{array}$ \\
\hline $\begin{array}{l}\text { Videos can be played offline after } \\
\text { being downloaded } \\
\text { Very familiar in the community } \\
\text { Safety of saved videos } \\
\text { Unlimited video duration }\end{array}$ & $\begin{array}{l}\text { Not able to provide material in the form } \\
\text { of grammar or qawa'id }\end{array}$ \\
\hline
\end{tabular}




\section{Conclusion}

Based on the results and discussion, it can be concluded that YouTube and Google Drive media can be used for Online Arabic Learning by the educators. Educators can save videos on YouTube with the display that attracts students learning interest and is able to make students learn well according to the video instructions. Learning videos can be arranged according to the material taught. Learning Arabic using Google Drive is able to improve learning outcomes about $11.07 \%$ from the previous one. The use of YouTube and Google Drive media is also inseparable from the strengths and weaknesses and it can be a consideration for educators in using them for learning.

\section{References}

[1] J. Kim, "Learning and Teaching Online During Covid-19: Experiences of Student Teachers in an Early Childhood Education Practicum," Int. J. Early Child., vol. 52, no. 2, pp. 145-158, 2020, doi: 10.1007/s13158-020-00272-6.

[2] M. Ritonga, A. Nazir, and S. Wahyuni, "Pembelajaran Bahasa Arab Berbasis Teknologi Informasi dan Komunikasi," Arab. J. Pendidik. Bhs. Arab dan Kebahasaaraban, vol. 3, no. 1, pp. 1-12, 2016, doi: http://dx.doi.org/10.15408/a.v3i1.2879.

[3] H. Mardiana, "Lecturers' Adaptability To Technological Change And Its Impact On The Teaching Process," J. Pendidik. Indones. |, vol. 9, no. 2, pp. 275-289, 2020, doi: 10.23887/jpiundiksha.v9i2.24595.

[4] S. Dhawan, "Online Learning: A Panacea in the Time of COVID-19 Crisis," J. Educ. Technol., vol. 49, no. 1, pp. 5-22, 2020, doi: 10.1177/0047239520934018.

[5] M. K. Ali and H. Maksum, "Utilization of E-Learning-Based ICT Learning Using the Google Classroom Application During the COVID-19 Pandemic," J. Educ. Res. Eval., vol. 4, no. 4, pp. 373-379, 2020.

[6] Januar, A. Rahmi, Andryadi, Hadini, and Yudelnilastia, "Utilization of Information Technology Media and Communication in Distance Learning During the Covid 19 Pandemic," in 2nd Bukittinggi International Conference on Education (BICED) 2020, 2021, pp. 1-7, doi: 10.1088/1742-6596/1779/1/012043.

[7] Y. K. Dwivedi et al., "Setting the future of digital and social media marketing research: Perspectives and research propositions," Int. J. Inf. Manage., no. July, pp. 1-37, 2020, doi: 10.1016/j.ijinfomgt.2020.102168.

[8] M. Iqbal et al., "Using Google form for Student Worksheet as Learning Media," Int. J. Eng. Technol., vol. 7, no. 3.4, pp. 321-324, 2018.

[9] N. Iivari, S. Sharma, and L. Ventä-olkkonen, "Digital transformation of everyday life - How COVID-19 pandemic transformed the basic education of the young generation and why information management research should care?," Int. J. Inf. Manage., vol. 55, no. June, pp. 1-6, 2020, doi: 10.1016/j.ijinfomgt.2020.102183.

[10] Fauzan and F. Arifin, "The Effectiveness of Google Classroom Media on the Students' Learning Outcomes of Madrasah Ibtidaiyah Teacher Education Department," Al Ibtida J. Pendidik. Guru MI, vol. 6, no. 2, pp. 271-285, 2019.

[11] A. K. R. Nasution, "YouTube as a Media in English Language Teaching (ELT) Context: Teaching Procedure Text," J. Ultim. Res. Trends Educ., vol. 1, no. 1, pp. 29-33, 2019.

[12] M. T. Yaqub, "Developing Speaking Skill in Arabic Learners: A Proposal for Integration of Product and Process Approaches," Eur. Sci. Jounal, vol. 8, no. 29, pp. 140-149, 2012.

[13] W. A. A. bin W. Daud, K. T. Wong, M. T. A. Ghani, and S. B. Ramli, "Gender differences in Learning Arabic Language Proficiency via M-learning among Malaysia University Students," J. Lang. Linguist. Stud., vol. 17, no. 2, pp. 1069-1082, 2021. 
[14] B. Pratiwi and K. P. Hapsari, "Kemampuan Berpikir Tingkat Tinggi Dalam Pemanfaatan YouTube Sebagai Media Pembelajaran Bahasa Indonesia," J. Ilm. Sekol. Dasar, vol. 4, no. 2, pp. 282-289, 2020.

[15] D. Mubshirah, "Hubungan Minat Siswa Belajar Bahasa Arab dengan Standar Nasional Pendidikan di MAN Aceh Barat (The Correla tion between Student's Interest in Learning Arabic and National Education Standard at Islamic Senior High Schools in Aceh Barat),” J. Ilm. Didakt., vol. 21, no. 2, pp. 221-235, 2021. 